\title{
Recovering the heritage and building traditions of the village of Tacora, Chile
}

Recuperando el patrimonio y las tradiciones constructivas del pueblo de Tacora, Chile

Recuperação do património e tradições de construção da aldeia de Tacora, Chile

\begin{abstract}
Resumen $\mid$ Resumo
Tacora is a village in the Chilean highlands with an extraordinary natural and cultural landscape. During the last years, its population has migrated massively to the city of Arica. In 2018, the community and the Fundación Altiplano organized a training program for the restoration of the façades of its buildings. The program employed and qualified community members in traditional building trades related to construction with earth, stone and wood. This training program opens up a horizon of new opportunities for sustainable development related to the extraordinary cultural heritage of Tacora.
\end{abstract}

Tacora es un poblado del altiplano chileno con un extraordinario paisaje natural y cultural. En los últimos años ha sufrido un fuerte despoblamiento hacia la urbe de Arica. En 2018 su comunidad y la Fundación Altiplano llevaron a cabo un programa de capacitación para la restauración de las fachadas de sus viviendas. El programa empleó y capacitó a miembros de la comunidad en oficios tradicionales relacionados con la construcción con tierra, piedra y madera. El programa de capacitación abre un horizonte de nuevas oportunidades para el desarrollo sostenible en torno al extraordinario patrimonio cultural de Tacora.

Tacora é uma localidade da planície chilena com uma paisagem natural e cultural impressionantes. Nos últimos anos sofreu um forte êxodo populacional em direcção à cidade de Arica. Em 2018, a sua comunidade e a Fundación Altiplano realizaram um programa de formação em restauração de fachadas das suas moradias. O programa empregou e formou membros da comunidade em ofícios tradicionais relacionados com a construção com terra, pedra e madeira. O programa de formação abre um horizonte de novas oportunidades para o desenvolvimento sustentável em torno ao extraordinário património cultural de Tacora. 
Virgen del Carmen Church (All images used to illustrate this essay belong to the Fundación Altiplano)

1: View of the village and the Tacora volcano

2: Site Map. The restored houses are highlighted in grey and the restored buildings for different

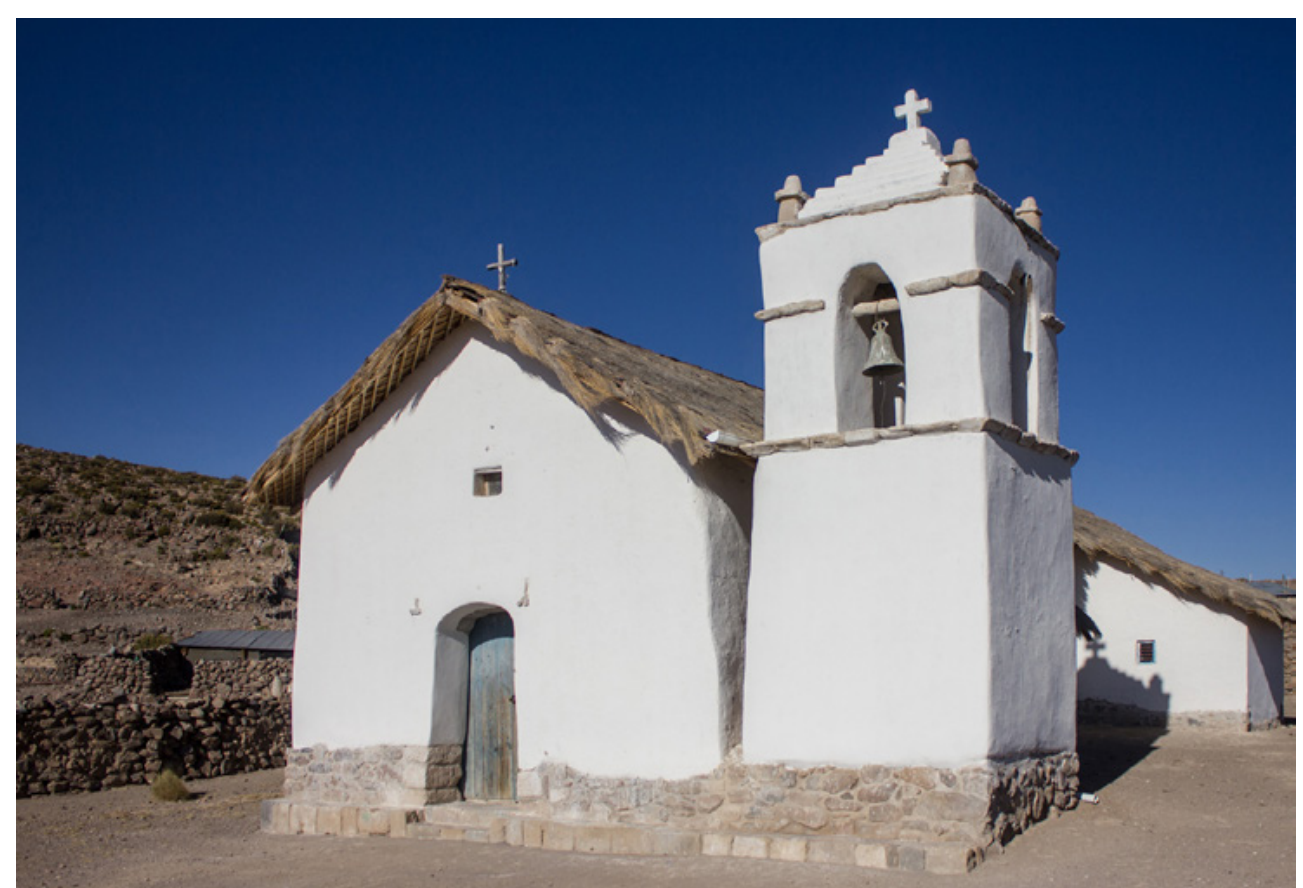

Tacora is a village located at an altitude of 4,090 metres in the region of General Lagos, in northern Chile. Founded as the main centre of an Inca community, its history is closely linked to sulphur extraction, which began towards the end of the 19th century, and was later facilitated by a railway connection with La Paz and Arica. Already in decline after the Second World War, in 1967 the extraction ceased completely and the population began to migrate and settle on the coast.

Although only four people now live permanently in Tacora, the old residents still maintain a strong relationship with the village: they return periodically for the fiestas patronales (patron saint festivals) and have created various associations.

In response to the rigid climate, which allows for breeding livestock but not growing crops, houses are arranged in aggregations of simple, single-storey, rectangular volumes. Their walls are built in rammed earth or adobe with small openings. The original thatch has been replaced by corrugated sheets on single and double pitch roofs. services in blue
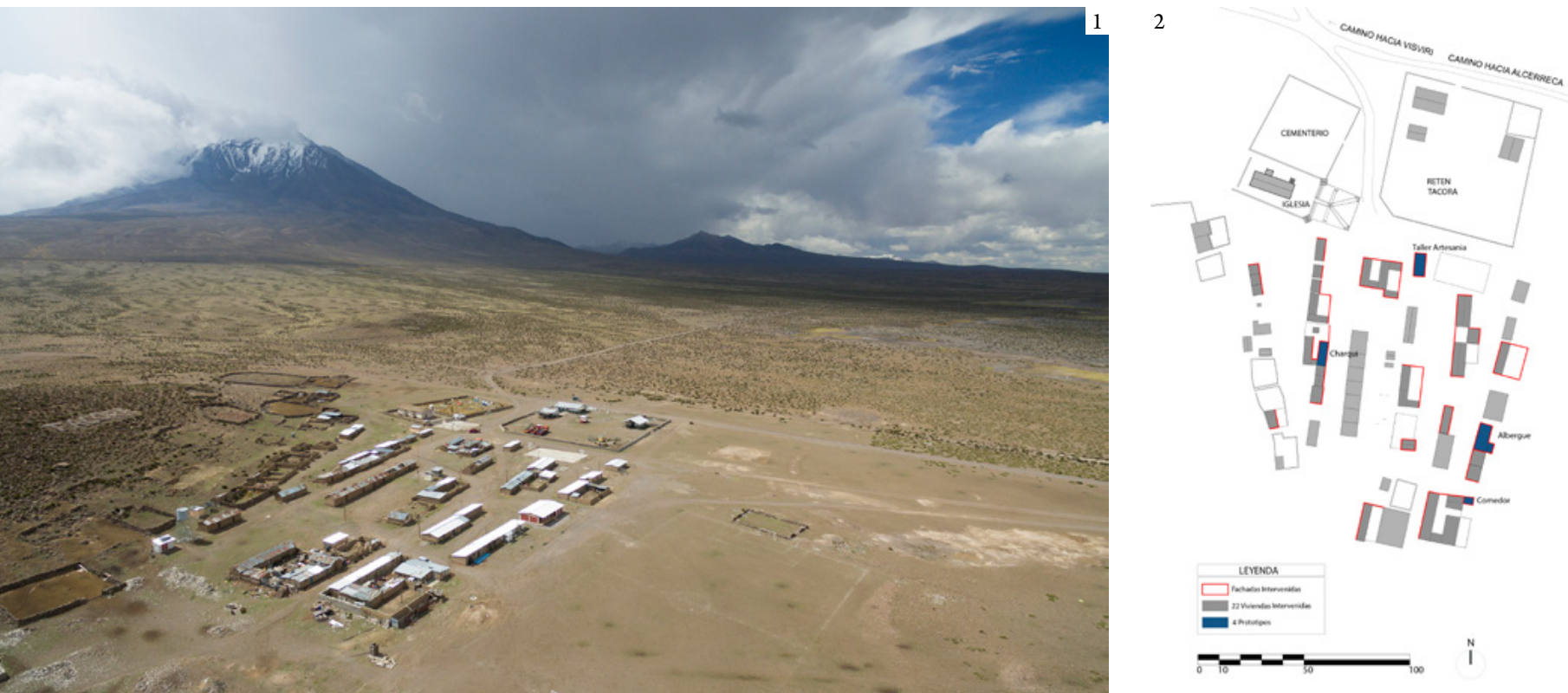

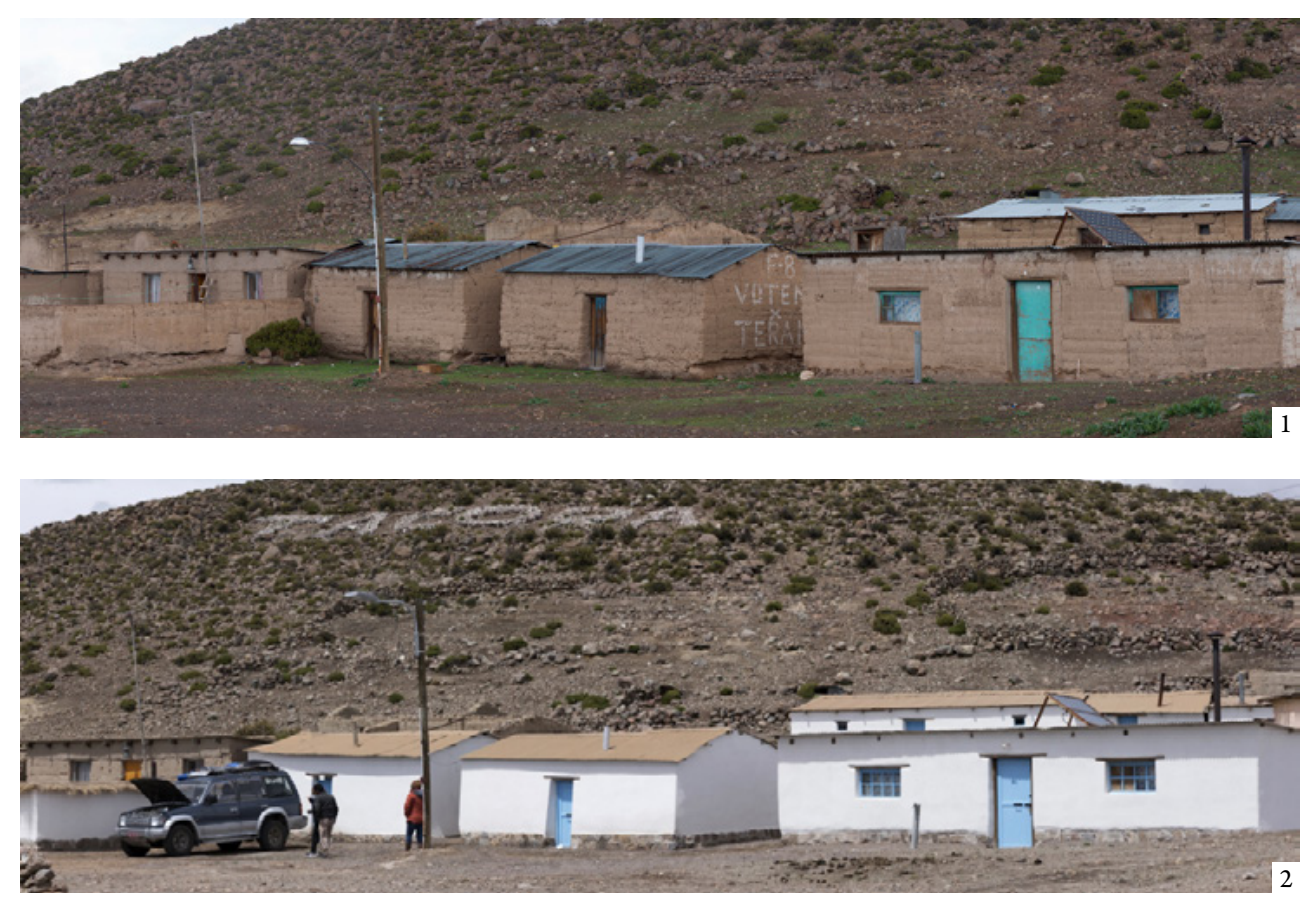

In 2016 the local community entrusted the Fundación Altiplano (FA), a Chilean nonprofit organization, to rehabilitate their houses. They had cooperated with FA in 2012 in the restoration of the Virgen del Carmen Church (late 18th century). The "Programa de Capacitación para la Restauración de Fachadas en Viviendas Patrimoniales de Tacora” (Training Program for the Restoration of Façades of the Heritage Homes in Tacora) was launched in February 2018.

A team of architects, anthropologists and historians began research aimed at understanding the historic landscape through written sources from colonial archives, the inhabitants' verbal accounts, and archaeological findings (Pereira and Yuste 2019). Materials, construction techniques and the current condition of the local buildings were investigated through a field survey. They were found to be mostly in a critical condition, due to lack of maintenance and frequent earthquakes. A comprehensive restoration was therefore urgently required.

The main damages were repaired with minimal and reversible interventions, using the shared formal language of local architecture and respecting the characteristics of the rural culture of these highlands.
1 and 2: The houses of the village before and after their restoration
1: Process of reconstruction of a rammed-earth wall

2: Wooden reinforcement of a rammed-earth wall
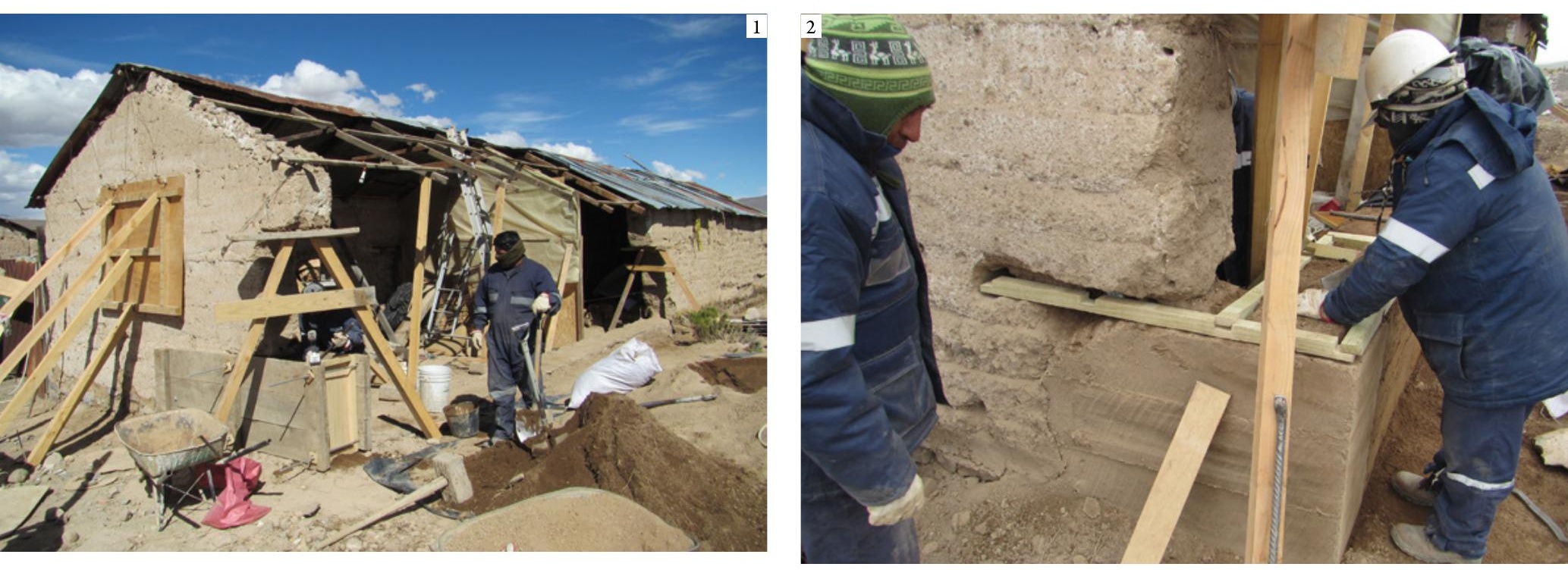
As well as recovering the façades of 52 buildings, the structure of four buildings was fully restored to serve as an example for possible future interventions, though modifying their original function. Priority was given to tourist services: a restaurant and a hostel, which provided food and accommodation for the builders, a weaving workshop and a charqui (dried meat) shop.

Alongside the recovery of the buildings themselves, the aim of the intervention was to revive traditional building knowledge; indeed, local inhabitants were offered jobs in heritage restoration works. An even more ambitious goal was to broaden the inhabitants' perspectives, to contribute to the local families' economy and to raise awareness of the opportunities provided by their tangible and intangible heritage as assets with regard to tourism and identity.

A cornerstone of FA's work is its relationship with the communities, to whom the heritage belongs, and who safeguard and keep it alive. In addition to providing technical support, a model based on the work with the local community was implemented, involving them in an open, participatory and interdisciplinary process, and giving them an active role during the construction phases. In Tacora, periodic meetings were organised, allowing the community to participate in identifying which façades and exemplary buildings should be selected to work on as well as choosing the finishings for those works. The traditions of the community were also respected: from the ritual of asking permission to begin the works, to the patron saint festivals and the closing ceremony.

The Escuela Taller (Training Workshop) methodology was applied to generate local know-how to ensure the conservation and maintenance of the heritage. Under the supervision of the master craftsmen, the restoration was set up as a field school offering jobs as adobe master, stonemason or carpenter to the locals. Theoretical lessons, given by specialists in architectural restoration and conservation, archaeology, traditional techniques and sustainable development, helped them to acquire technical and practical skills. Eleven people participated in this program, including six members of the local community.

Locals and youths from the region were also invited to participate in volunteer days and to attend the lectures.

The interventions employed local techniques and solutions, without altering the architectural character of the place. Missing or eroded stone basements were restored; collapsed or detached portions of walls were rebuilt; cracks and fissures were repaired with earthen mortar injections, filled with adobe bricks or with volcanic stones and earthen mortars. In some gables, masonry was replaced by lightweight quincha: a local traditional structure made of wood and reeds which is filled

1: Making of a caruna with a mixture of earth and straw.

2: A caruna being placed on a roof
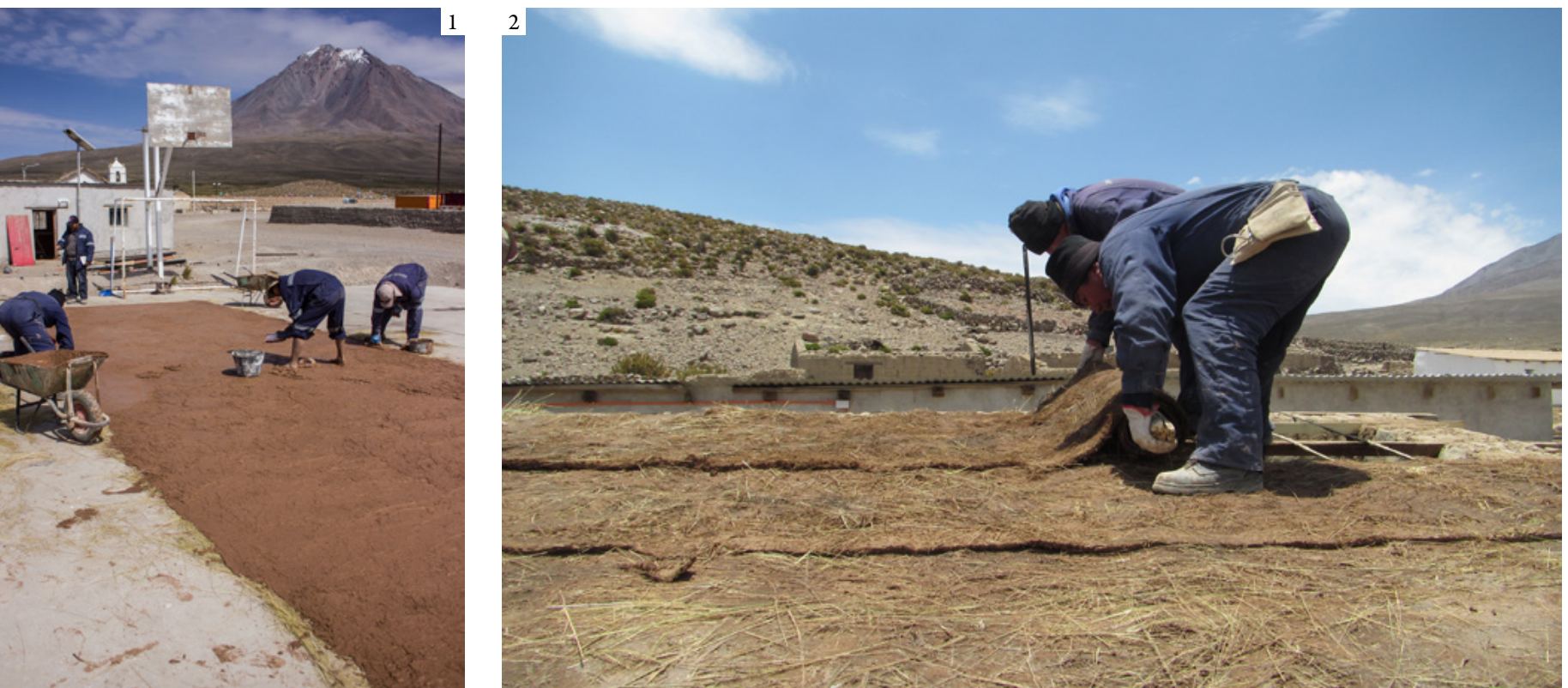


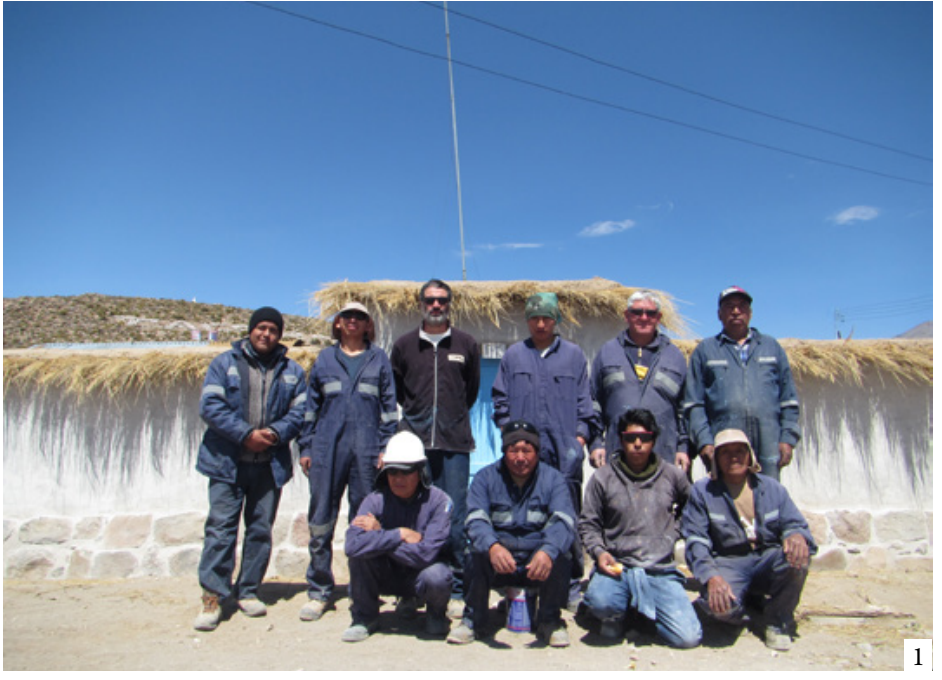

In order to improve the seismic resistance of the restored buildings, low-tech solutions based on studies by Julio Vargas Neumann - a professor at the Pontificia Universidad Católica del Perú - were used, such as biaxial nets, wooden reinforcements and geomats.

Walls were rendered with mortars made of lime and sand, and painted with lime mixed with baba de tuna (water in which pieces of local cactus have been previously immersed), to protect them from weathering.

The roofs of the exemplary buildings were disassembled and reassembled after introducing top plates, on which joists and train tracks ${ }^{1}$ were repositioned, or replaced where necessary. In the hotel and the restaurant a double layer of totora (southern bulrush) mat, glass wool insulation, a waterproofing membrane and a substructure of battens to support the metal sheets were used.

In the weaving workshop and the shop an oral tradition, which was still remembered by one of the workers, was recovered: caruna was laid on cowhide laces, braided to the rafters. Caruna is an insulation mat obtained by first placing some straw randomly on a flat surface, then pouring earth and baba de tuna, and finally treading on the mix. Once it is almost dry, it is cut and rolled (Bocci 2019).

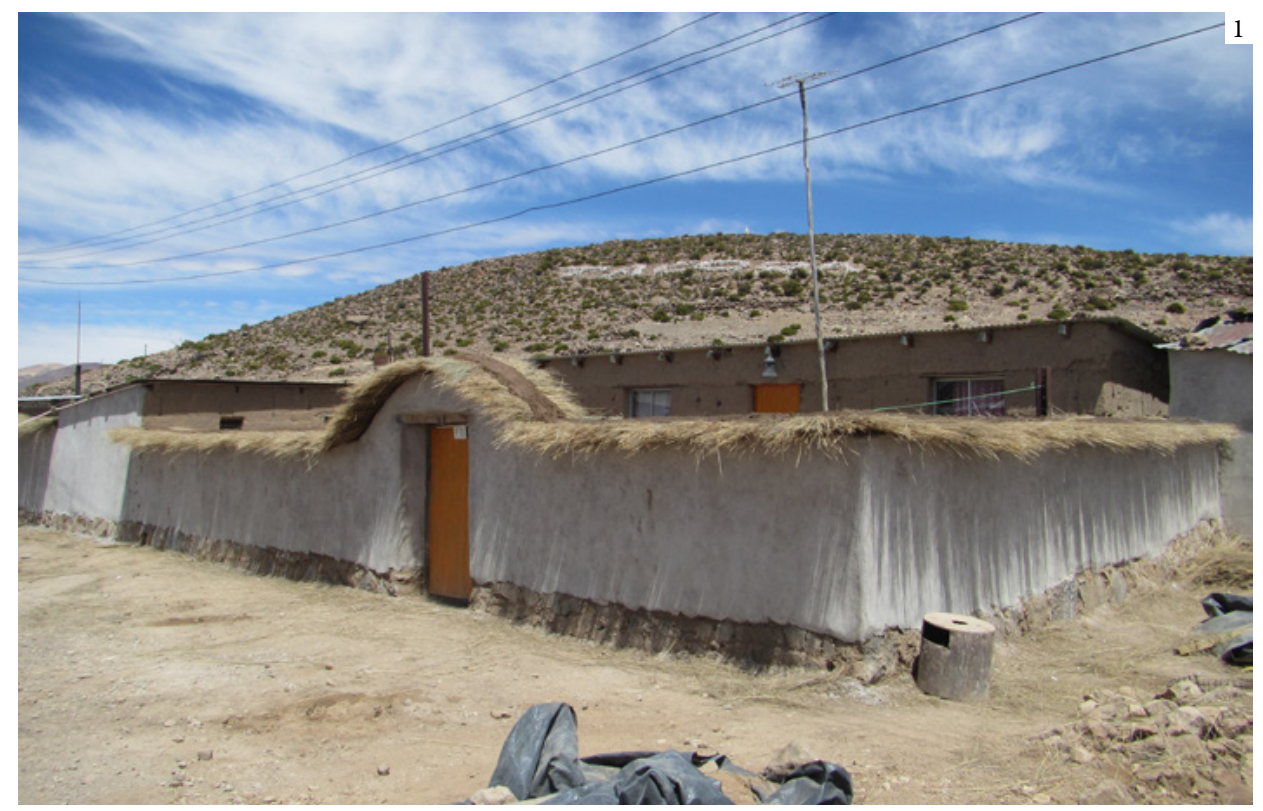

1: Crowning of a perimeter wall

2: Cutting of the cowhide to make the laces used in the roofing

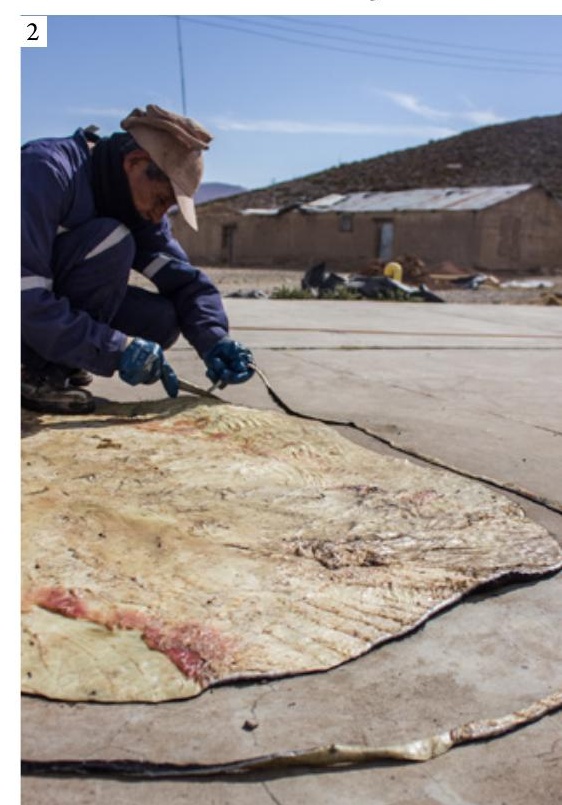


In the remaining houses the intervention was limited to substituting the metal sheets (maintained for their easy availability and low maintenance) where necessary, and painting both the new and existing sheets using a colour similar to straw, to reduce reflection and to protect them from rusting.

Coping stones were used for crowning the courtyard walls. Cross bundles of paja brava (Peruvian feather grass) - harder and more resistant than ordinary straw - were then put in place, and finally earth mortar finishings were applied.

To sum up, local materials were used almost exclusively: earth, stone, gravel and sand came from the surrounding area; cactus, straw and totora were collected at lower altitudes, along the road to Arica; the cowhide for the laces was provided by a nearby farm.

During the final ceremony, the Manual de Mantenimiento (Maintenance Manual) was given to all the beneficiaries, providing guidelines on how to proceed in the case of building decay in future. From that moment on, all members of the community symbolically became the bearers of the knowledge acquired through this program. They were thus recovering the wisdom of their ancestors, which will allow them to preserve their homes (Pereira and Yuste 2019).

Some locals who have worked in this program established a construction company specialised in traditional building techniques, to which FA is offering technical support. In the future they may be in charge of a second phase of Tacora's rehabilitation. Thus, the program was not just about building restoration but also the sustainable development of this remote Andean community.

In order to help them become less dependent on external support, FA has supported the community in establishing a management plan to be implemented after the FA finishes its work there (Yuste 2019).

${ }^{1}$ The train tracks, sometimes used as beams in buildings, represent a memory of the steam railway line which was active in Tacora from 1925 to 1966 . The line was mainly used to transport sulphur, extracted from the Tacora volcano. This line was connected with the La Paz railway line.

\section{Bibliography $\mid$ Bibliografía | Bibliografia}

Bocci, Martina. 2019. Cile, così rivivono i pueblos. Giornale dell'architettura. https://ilgiornaledellarchitettura.com/ web/2019/01/24/cile-cosi-rivivono-i-pueblos/ (consulted on 24/08/2020).

Pereira, Magdalena; and Yuste, Beatriz. 2019. El Último Mallku. Paisaje cultural de Tacora. Arica: Fundación Altiplano.

Yuste, Beatriz. 2020. Sustainable Conservation in the Andean rural communities. In Bocci, Martina; Mazelli, Redina; and Bocco, Andrea (ed.). 2020. Rehabilitation of traditional heritage and local development. Torino: Politecnico di Torino (In print).

\section{Biographies | Biografías | Biografias}

\section{Martina Bocci}

She graduated in Sustainable Architecture at Politecnico di Torino, with a Master thesis on earth construction techniques in Europe and Brazil. She is currently working on a Ph.D. in Urban and Regional Development at the InterUniversity Department of Urban and Regional Studies of the Politecnico di Torino (DIST). Her research is focused on the role of the conservation and transmission of traditional construction techniques in local development. She is a cofounder of Accademia nel Cantiere (AnC), a nonprofit organization carrying on the design, research and construction of sustainable architecture through the use of appropriate technologies and natural materials.

\section{Beatriz Yuste}

She is the head of heritage restoration projects in Fundación Altiplano. She graduated in Architecture and holds a Master's degree from the Universidad Politécnica de Cataluña. She specialized in design and management of sustainable restoration projects within the Templos Andinos of Arica and Parinacota/Ruta de las Misiones-Saraña Plan. 